\title{
Long-awaited autonomy in sight for SA's doctors
}

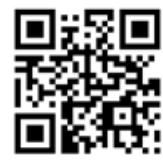

The long-awaited extraction of doctors - and possibly dentists - from the dysfunctional and shockingly administered Health Professions Council of South Africa (HPCSA), the defiant leadership of which face the sack, will not lack a helping hand from the country's largest doctor body. South African Medical Association (SAMA) Chairperson Dr Mzukisi Grootboom told Izindaba that SAMA immediately began drawing up a legal white paper for a new autonomous, self-regulatory body in 2012, when the Parliamentary Portfolio Committee on Health recommended this as the most pragmatic way forward. 'So the paper is obviously ready and we'll now hit the ground running and support the health minister to return to Parliament and change the Health Professions Act,' he said. He was speaking just weeks after the damning report on the HPCSA by a ministerial task team led by Prof. Bongani Mayosi, head of medicine at the University of Cape Town. Grootboom said his 17 500-member organisation had always believed that the independence, autonomy and self-regulation of doctors in any jurisdiction was to the benefit of the patient.

'It's an important ethical principle - any government that wants to take over control of any profession will never be doing it in the best interests of the patient', he stressed. $\mathrm{He}$ was referring to the controversial

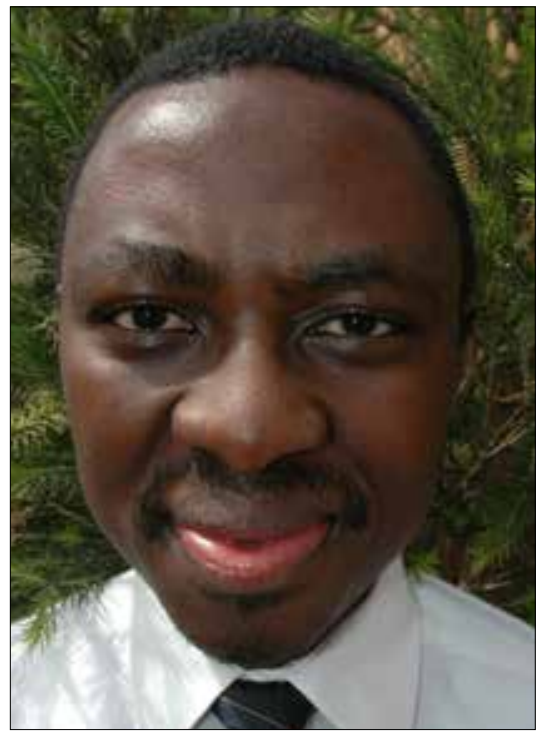

Prof. Bongani Mayosi, who led the ministerial task team probe of the HPCSA.
Health Professions Act, which puts control directly in the hands of the national health minister by allowing him to appoint the majority of the 32-member HPCSA, which is $90 \%$ funded by the registration fees of doctors and dentists. This forces doctors and dentists to rely on the largesse of the incumbent minister when it comes to their and their patients' best interests. While Dr Aaron Motsoaledi has arguably proved the most physician- and patient-friendly health minister yet, when added to HPCSA's current administrative chaos, the legal set-up is a recipe for failure and controversy. There are 12 professional health boards in the HPCSA, the Medical and Dental Professions Board (MDPB) being the largest, but with hugely diluted political and practical clout.

\section{SAMA chair shares his own HPCSA experiences}

Outlining his own experience of the HPCSA, Grootboom said that early every January he received scores of calls from irate parents wanting to know when their newly graduated children would be registered. 'They don't draw a distinction between SAMA and the HPCSA, so it reflects on us. It's mind-boggling how this situation was allowed [to get so bad]. To get registered is like pulling an elephant's tooth.' When it came to the HPCSA's statutory duty to oversee the accreditation of hospitals as training institutions, committee after committee drew up reports giving the facilities reprieves with the excuse that they were 'still suffering from the effects of apartheid' and promising to return for a follow-up assessment the following year. 'Yet the truth is the facilities are getting worse - people need to be honest enough to say such low standards shouldn't be allowed.' Doctors (and their patients) faced with a professional conduct complaint to the HPCSA had to wait up to 3 years or more before the matter was heard and/or resolved, with clinical input seldom if ever prioritised. As for foreign-qualified physicians, they never knew where they stood, as clearly outlined, country-specific registration and vetting procedures were inconsistently applied, resulting in sorely needed, wellqualified doctors either giving up or living in limbo doing menial jobs. Izindaba is aware of several cases of HPCSA administrative

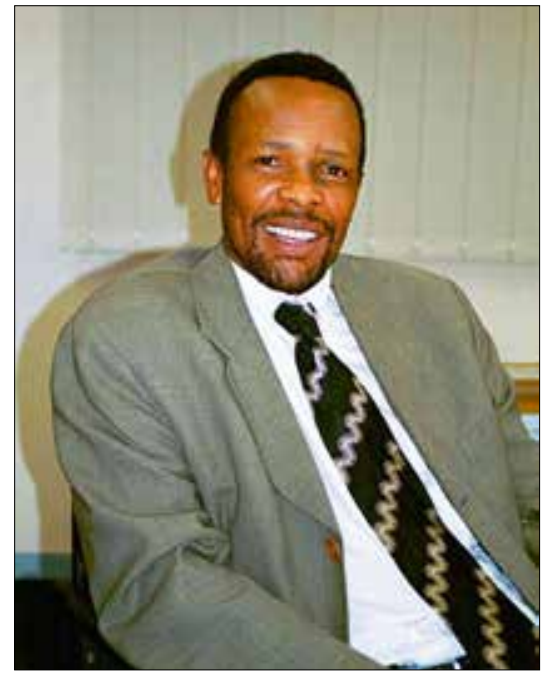

HPCSA President Dr Kgosi Letlape.

clerks committing fraud or submitting false documentation to the MDPB's foreign qualifications vetting committee - in one foreign neurosurgeon's case, the committee chaired by Mayosi himself. Ironically, ensuing internal probes inevitably choke the doctor supply pipeline even further, as every application automatically becomes suspect.

\section{Leadership trio 'unfit for office'}

Mayosis fact-finding probe - widely and correctly predicted to be hard-hitting and without fear or favour - comes after the HPCSA Board failed to act on damning earlier forensic reports, or to claim hefty court-ordered legal fees from its Chief Operating Officer, Advocate Tshepo Boikanyo. Boikanyo, along with Chief Executive Officer Buyiswa Mjamba-Matshoba and Head of Legal Services Phelelani Khumalo, refused to give evidence to the ministerial task team that found them 'unfit for office.' Boikanyo had earlier taken the HPCSA to court for not accepting his application to be CEO losing with costs. The money was never recouped from him, while a KPMG forensic report concluding that he was involved in 'unauthorised, irregular and/or fruitless and wasteful expenditure' was ignored. The KPMG findings centred on the purchase of an Oracle Information Technology system, the cost of which ballooned from ZAR14 million to around ZAR40 million. Mayosi's task team said that Mjamba-Matshoba's refusal to appear before them 'justifies the 
drawing of an inverse inference against her', and could amount to 'insubordination' given that she was appointed by the self-same minister who tasked them. Their report found that the HPCSA was suffering from 'multisystem organisational dysfunction'. It recommended that the Council be unbundled into at least two entities: the historic MDPB, which constitutes a third of the current HPCSA membership, and a Health and Rehabilitation Council for the rest of the professional membership. The new councils would join the South African Pharmacy Council, the South African Nursing Council and other autonomous councils in a 'Forum of Statutory Health Professions Councils.

\section{While Motsoaledi has arguably proved the most physician-and patient-friendly health minister yet, when added to the HPCSA's current administrative chaos, the legal set-up is a recipe for failure and controversy.}

Said Dr Mark Sonderup, Deputy Chairman of SAMA: 'Nobody is more delighted about this recommendation than SAMA, which has been increasingly frustrated by the medical and dental board of the HPCSA's cavalier attitude towards doctors.
We've been lobbying for this for the past six years. The MDPB's response to repeated SAMA petitions was that matters could be resolved 'in-house' (i.e. within the HPCSA's existing structures). A former deputy chairperson of the MDPB, Prof. Marietjie de Villiers, reflected this to Izindaba: 'The Board itself [MDPB] is fine. It's the HPCSA administration that is dysfunctional. The number of boards is not the problem - it's the admin culture.' She served as deputy to Prof. Thanyani Mariba on the MDPB in 2010, and said that when the original South African Medical and Dental Council was dismantled for absorption into the HPCSA 'we all rejoiced that we were now all together. I'm astounded that they now want to go back.' De Villiers, Deputy Dean of Education in the Faculty of Medicine and Health Sciences at Stellenbosch University, said that she served as Dean's Representative on the HPCSA's Postgraduate Education and Training Committee, 'but our decisions were not implemented'.

\section{Leadership remains in place}

Dr Kgosi Letlape, newly appointed President of the HPCSA, said he met with Motsoaledi to hand him an interim report compiled after he convened a special Council meeting just after the task team findings. 'I cannot reveal the contents, but due process requires us to respect the rights of the people involved, and the processes of the Council', he said. He added that the leadership trio so severely criticised would therefore remain in place at least until the Council had compiled an interim report on how it would respond to the task team's findings, due within 6 months.

'We have to deal with the issues raised. These are not things you deal with in one day. These challenges are things that came about over many years,' Letlape added. A sign of things to come may lie in the changes Motsoaledi rang in his annual appointment of a new Council just weeks after Mayosi's report. Of the 32 members, 24 are new appointees. When it was put to Letlape that the task team report was 'pretty damning', he responded: 'It's not for me to agree with that. The report speaks for itself.'

The HPCSA's stated mission is 'to protect the public and guide the professions, something increasingly satirised by members of both key stakeholder groups over the past 15 years.

As newly appointed SAMA President Dr Denise White observed hopefully: 'The key will be whether they carry out the task team's recommendations.'

\section{Chris Bateman}

chrisb@hmpg.co.za

S Afr Med J 2016;106(1):7-8.

DOI:10.7196/SAMJ.2016.v106i1.10414
Dear Doctor

\section{MED $อ$ MAIL O}

The South African Medical Association SAMA recognises the seriousness of the current climate change emergency and aims to position itself to spearhead the involvement of doctors in national efforts to address of climate change in South Africa. As of November 2015, five South African provinces - KwaZuluNatal, Mpumalanga, North West, Limpopo and Free State - have been declared drought disaster areas, as dry conditions and heat waves of above $40^{\circ} \mathrm{C}$ maximum temperatures persistently affect many areas. This has dire consequences on health and calls for urgent, practical measures.

The world is at a sensitive stage with regard to climate change, facing one of the greatest global threats amidst failing international negotiations. The upcoming twenty-first session of the Conference of the Parties (COP21) will take place from 30 November to 11 December 2015, in Paris, France. SAMA looks forward to positive outcomes from the COP21, whose objective is to achieve, for the first time in over 20 years of United Nations negotiations, a binding and universal agreement on climate, from all the nations of the world.

Although SAMA will not be attending the COP21, SAMA calls upon all its doctors to remain interested in the event and to take serious recognition of climate change related health consequences, while upholding the recommendations of the World Medical Association as outlined in the WMA Declaration on Climate Change. In the interest of "green medicine", medical professionals must take personal responsibility in exercising good environmental stewardship. Resources on practicing "green medicine" is available from http://www.mygreendoctor.org.

More information on the COP21, WMA Declaration on Climate Change and a plea to physicians to green office space are found in the links below:

http://www.cop21 paris.org/about/cop21

http://www.wma.net/en/30publications/10policies/c5/

http://www.wma.net/en/40news/20archives/2015/2015_41/index.html.

SAMA Corporate Communication, 24 November 2015 